\title{
LA RESTAURACIÓN DIDÁCTICA DE LA IGLESIA DE SANT QUIRZE DE MUNTANYOLA (CATALUÑA, ESPAÑA)
}

\author{
(THE DIDACTICAL RESTORATION OF THE CHURCH OF SANT QUIRZE OF \\ MUNTANYOLA, CATALONIA, SPAIN)
}

Antoni González Moreno-Navarro, Arquitecto

Fechat de recepeion: 1.111193

Jefe del Servicio del Patrimonio Arquitectónion Iosal de la

$128-46$

Diputación de Barcelona

\section{RESLMEN}

La islesia parroquial del municipio de Muntanjola, un pequeño templo de origen medieval, sorprendia al visitante por consernar. aumque fiera con mal estado, toda la decoración barroca de los siglos XVII Y XITII. Se trata de un hecho inhabitual en Cataluna, donde, bien las remeltas sociales, bich ma iomoclasta purificación en busca de las trazas medierales, han despojado a la mayor parte de los edificios religiosos antigues de las decomionens de épocas más modernas.

Esta singular circunstancia indujo a plantear una "restanración didáctica" que devolviera al temple el esplendor de str imagen barroca, con la doble intención de congraciar a los parroquianos con sul templo y de colaborar e'n la reinindicación de un arte de' sacreditado en Caraluña por atestiones ajemas a heidos arquitectónicos o artísticos.

El descubrimiento de alonnos clementos romanicos con suficiente centidad también sugirió su puesta en pralor para que los visitantes pudicran leer en los muros la evolución histórica de la fábrica $y$ los habitantes del hegar signicran sintiondose orguthosos del pasado mediepal de su iglesia parroquial.

\section{$S L M M A R Y$}

The parish diurth of Muntanyola, a small temple of mediacral origin, used to surprise its visitors for having presened, although in por condition, its baroque decoration from XVII and XVIII This is a rare case in Catalonia, where either social riots or an iconodastic purification in search of mediactal designs, hane left the majority of ancient religions buildings bare of decorations of more recent times.

This exceptional circumstance led to the idea of a "didactic restoration "which would retum the splendour of its baroque appearame to the temple. Such an idea was guided by ture motives: one was to incratiate the parishioners with their temple and the other to collaborate in the recovery of an art that had becen discredited in Catalonia for reasons which are alien to arquitectural and artistic facts.

The disconery of some Romanic elements of sufficient importance also suguested its significance which meant that the pisitors conld read on the walls about the building's crolution through history and the inhabitants could continuc feeling proud of the mediactal past of their parish church.
La actuación en la iglesia de Muntanyola tiene su origen en la petición que en enero de $198+$ hizo el alcalde al presidente de la Diputación de Barcelona para que esta institución. en el ejercicio de su competencia de cooperación con los municipios, se hiciera cargo de una restauración que. "desgraciadalmente" -decía la instancia del alcalde-, "la despoblat- ción del municipio y de la parroquia impide encauzar como sería conveniente". Atendiendo a la titularidad eckesiástica del inmueble el convenio regulador de las obras y del uso del edificio fue firmado en 1987 por el entonces presidente de la Diputación, Antoni Dalmau Ribalta. y el obispo de Vic. Josep Maria Guix. 
Muntanyola se halla en la zona central de la provincia. Dista de Barcelona unos $80 \mathrm{~km}$ y unos tres cuartos de hora por autovía. Doce kilómetros la separan de Vic, la capital comarcal, judicial y diocesana. En su territorio, de unos $40 \mathrm{~km}^{2}$, unas doscientas personas, dedicadas fundamentalmente a la agricultura, viven diseminadas en masías, ya que hasta ahora no ha tenido el municipio ningún núcleo de población. La propia Casa de la Vila (Ayuntamiento) parece un
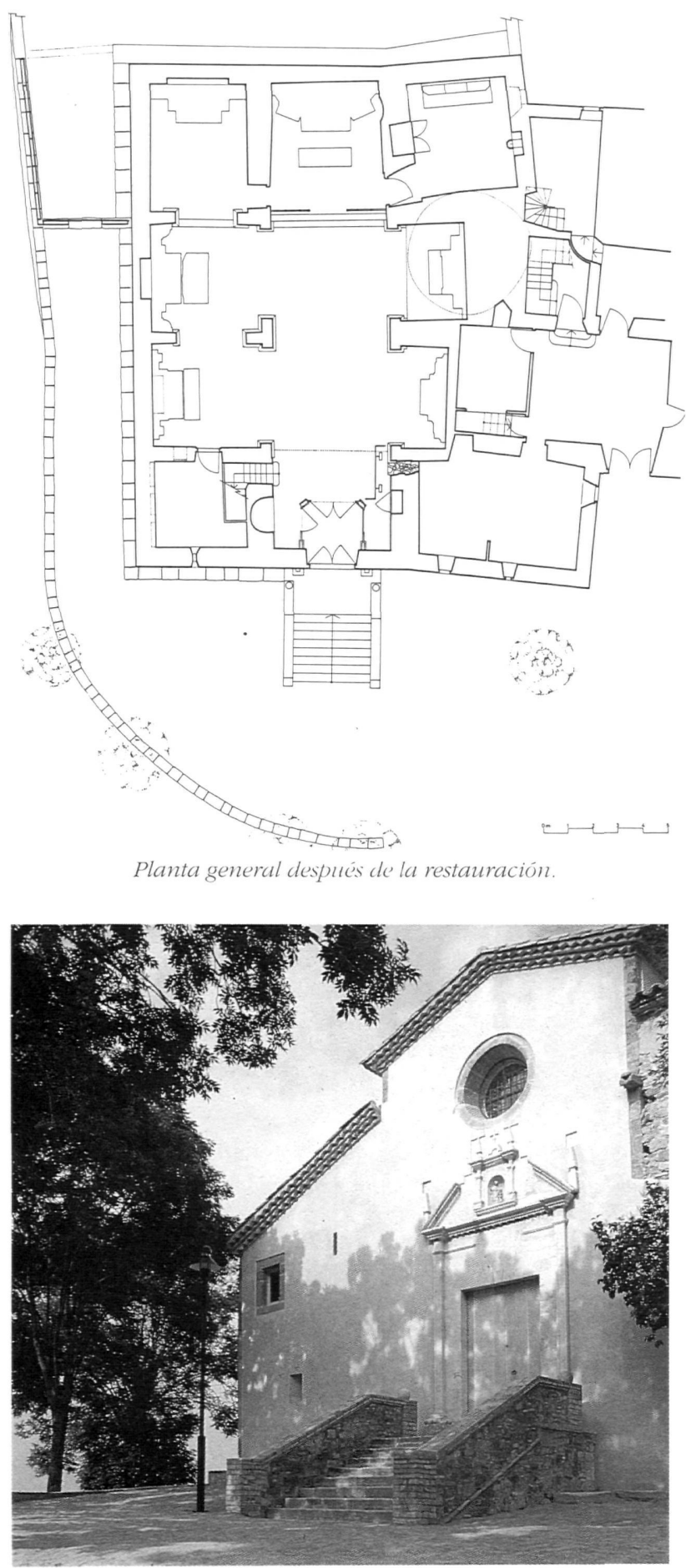

Fachada principal después de la restauración (fotos: Montserrat Baldomà). derrelicto abandonado por la Administración en medio del bello paisaje montañoso de Muntanyola; un paisaje que desde 1975 sufre una urbanización de segunda residencia que está transformando el carácter del municipio.

En el punto más alto del territorio (el topónimo Muntanyola deriva del latín Montaneola, diminutivo de Montanea, siendo su equivalente castellano, por lo tanto, colina o montecillo), a 808 metros sobre el nivel del mar, se halla, también aislada, la iglesia parroquial de Sant Quirze i Santa Julita.

\section{UN EDIFICIO SORPRENDENTE}

Cuando fuimos a visitar la iglesia por primera vez nos sorprendió un letrero colocado por nuestros compañeros de obras públicas que nos anunciaba un edificio románico. Era sin duda la mejor carta de naturaleza que un templo catalán podía presentar al visitante, pero lo cierto es que, a primera vista, la fábrica que teníamos ante nosotros ya no respondía a aquella cronología medieval. Se trataba de un conjunto de edificaciones, más uniforme que armónico, en buena parte en estado de ruina, cuyo destino sagrado anunciaba un altivo y decrépito campanario, y cuya datación aparente no se alejaba mucho de los siglos XVII o XVIII.

En el extremo septentrional de la fachada occidental -hecha de mampostería y recubierta sólo parcialmente ya por retazos de estuco colgados de los aleros- y en lo alto de una escalera hecha de remiendos, encontramos la puerta de la iglesia. Estaba enmarcada por una portada de piedra blanca, rota y desgastada, remedo payés de una arquitectura a la romana, presidida por los famosos mártires Quirico y su madre Julita, de tan truculenta hagiografía.

Cerca de la portada, en el ángulo noroeste del edificio, vimos el que parecía el peor mal de la fábrica: dos grandes grietas verticales, consecuencia de haber cercenado el terreno para abrir el camino que bordea el edificio, cuyo cimiento se había asentado tras quedar a la vista. Sin hallar en el recorrido exterior ningún dato que permitiera comprobar el origen románico de la iglesia, nos dispusimos a entrar.

Al atravesar el umbral, el cancel nos recibió con una fecha disuasoria: 1732. Y el interior tampoco podía ser más explícito: un espacio del más castizo barroco catalán, cuya planta, a simple vista, resultaba, no obstante, inhabitual (parecía tener dos naves, con capillas laterales en la de la derecha, la que correspondía al presbiterio). Sin duda, pensamos, era el 
resultado de una compleja evolución que los historiadores tendrían que averiguar.

Enseguida aquel espacio nos sugestionó. Nos atrajo la voluntad culta de una arquitectura de trazos clasicistas realzados por una pintura de mano popular, las cuatro cúpulas en hilera -una solución no muy frecuente por aquellas tierras-, y nos sorprendió agradablemente, sobre todo, que la iglesia conservara aún todos los retablos. Acostumbrados a que estos espacios barrocos nuestros hayan perdido casi siempre su ajuar litúrgico por causa de revueltas o en aras de una iconoclasta purificación en busca de los orígenes medievales, nos colmó de ilusión hallarnos ante una excepción.

El retablo del presbiterio aparecía casi entero, con la mayor parte de las imágenes, coronado por un pequeño pero amenazador arcángel San Miguel, casi colgado de una cúpula celestial salpicada de estrellas sobre un fondo de rutilante azulete. A la derecha, otro retablo era presidido por la sangrante, retorcida $y$, curiosamente, siempre sonriente imagen de San Sebastián. En la capilla contigua, otro, datado en 1797 , lo presidía la Inmaculada. Y enfrente, en la otra nave, el más bello y posiblemente el más anti- guo, era capitaneado por San Isidro (santo patrón aún de los payeses catalanes, por más que algunas autoridades se empeñen en promocionar un nuevo santo patrón autóctono). En la capilla vecina otra virgen presidía un retablo más moderno, de la misma época que el de la capilla del Santo Cristo, contigua al presbiterio.

Antes de salir pensamos que aunque no hubiéramos visto ni rastro de románico aquel edificio bien valía

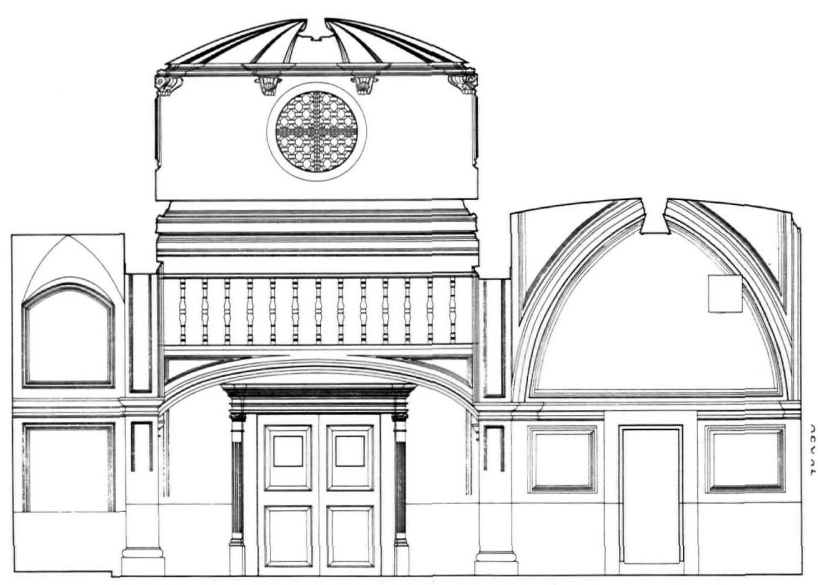

Sección transversal. Coro y cancel.

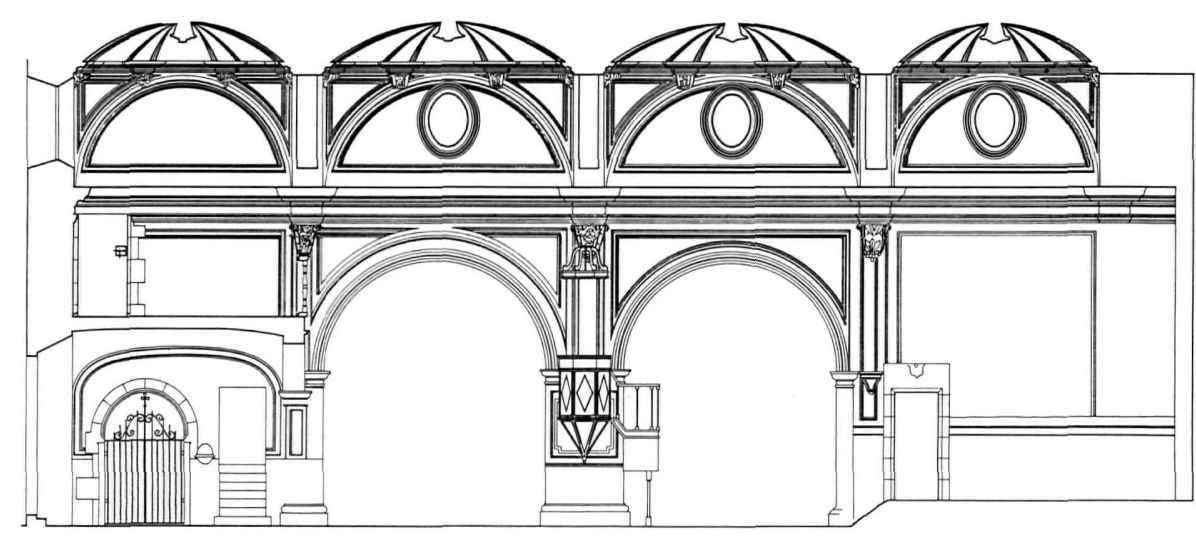

Sección longitudinal del lado del evangelio.

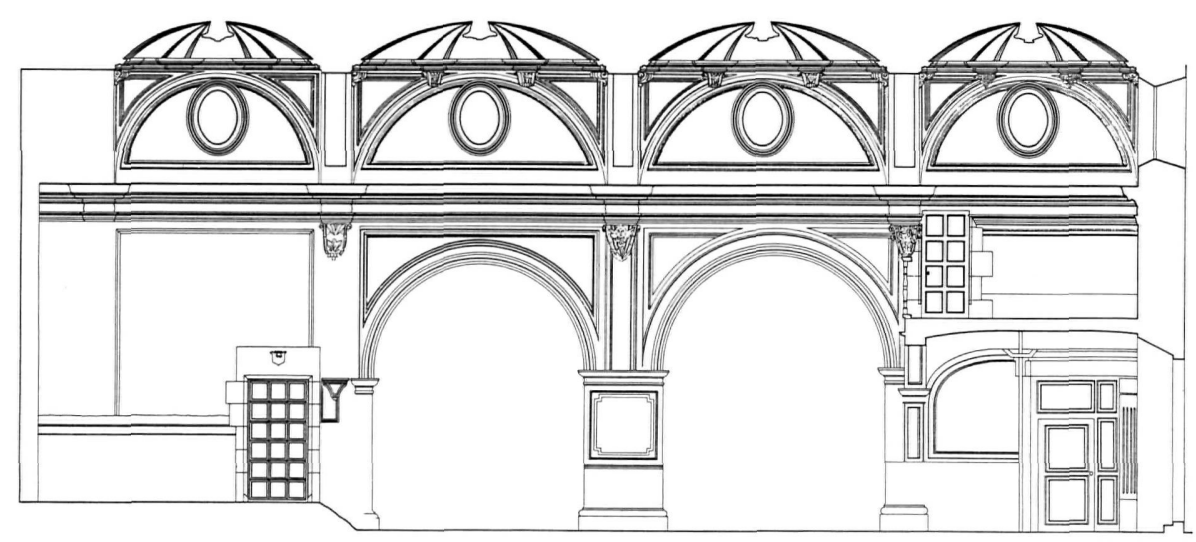

Sección longitudinal del lado de la epistola. 


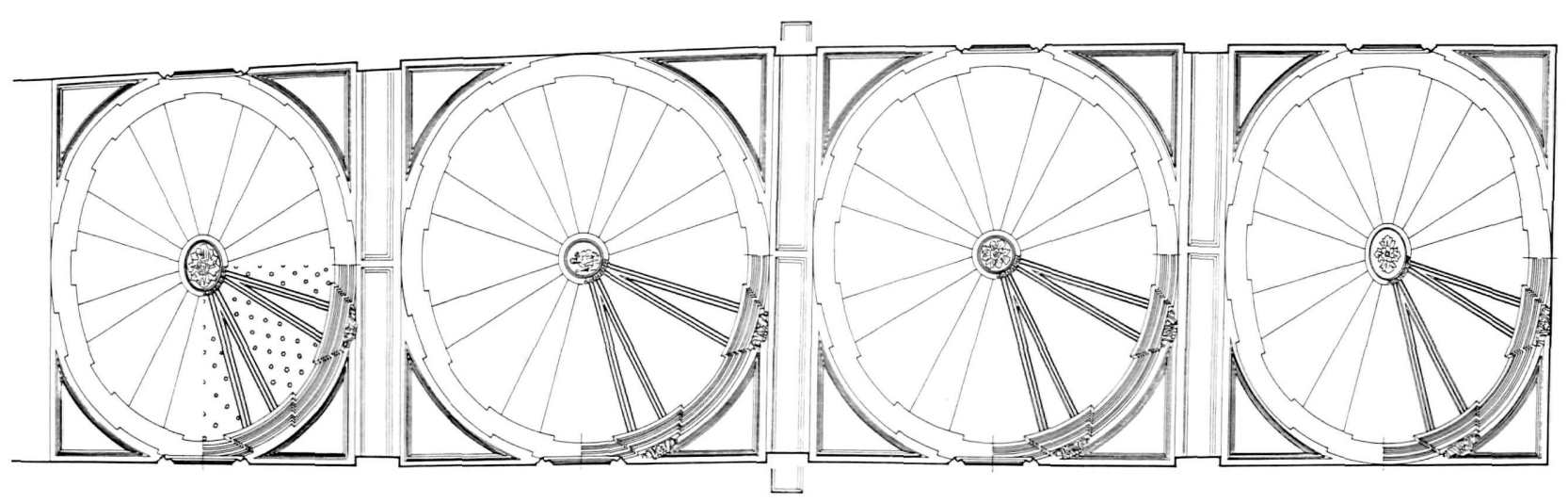

Planta cenital de la nave.

una restauración. Y averiguamos qué otros males le aquejaban y pudimos detectar la humedad proveniente de los tejados, las pequeñas grietas que quebraban los arcos, los desconchones, la suciedad: los síntomas habituales de la dejadez. Ese era, en definitiva, el principal problema del inmueble.

\section{OBJETIVOS Y MEDIOS DE LA RESTAURACIÓN}

Los trabajos realizados en Muntanyola se desarrollaron según el esquema metodológico de nuestro Servicio, que, como hemos explicado en otras ocasiones (1), se basa en la determinación de los medios en función del planteamiento riguroso de los objetivos después del análisis del monumento -considerado simultáneamente como documento histórico y como objeto de arquitectura-, y el de sus valores significativos y emblemáticos. Una consecuencia obvia de este método es programar las actuaciones con ambición, por lo que también en Muntanyola, como en más de una ocasión nos había ocurrido, se nos recriminó después que nuestro concepto de restauración traicionara en cierta manera el espíritu con el que se creó nuestro Servicio en 1914.

Jeroni Martorell, su primer director, dejó escrito, efectivamente, que debíamos procurar limitar los trabajos de conservación "a lo esencial para la estabilidad de los edificios". "Se procurará en primer lugar", decía, "el buen estado de las cubiertas y la defensa de los cimientos de la acción del agua... y cuando los medios lo permitan, se harán trabajos más considerables: vaciar los ventanales tapiados, descargar las bóvedas del peso de los tejados... ". Eso lo escribió en 1914. Y lo repitió en 1919 (2), es cierto. Pero después, ese bagaje doctrinal con que Martorell se inició en el mundo de la restauración, tan influido por las ideas anti-restauradoras de los primeros años de nuestro siglo, se fue enriqueciendo y matizando gracias al pragmatismo al que nos obliga la función pública.
Martorell comprendió -y de él lo hemos aprendido nosotros- que restaurar no es sólo sostener la materialidad del monumento heredado, sino también potenciar -incluso recuperar si se hubiera perdidosu significación colectiva. Y para ello es necesario, casi siempre, además de garantizar la estabilidad del monumento y mejorar su uso, devolverle su belleza, su atractivo para la comunidad, que es para quien, en definitiva, nosotros restauramos.

¿Qué debíamos hacer, pues, con la iglesia parroquial que el pueblo de Muntanyola ponía confiadamente en nuestras manos? Una vez planteados los objetivos derivados de la esencia documental del monumento (la irrenunciable investigación científica inherente a toda restauración), los objetivos esenciales genéricos derivados de la condición arquitectónica fueron tres: mejorar las condiciones físicas de la fábrica, mejorar el uso del edificio y potenciar su significación colectiva. Los dos primeros implicaban trabajos de consolidación y acondicionamiento de escasa relevancia técnica en un edificio como éste.

Para satisfacer el tercer objetivo -mejorar la relación significativa entre el edificio y sus usuarios-, repetimos comportamientos ya ensayados en otras obras del Servicio.

Pero casi desde un principio a esos objetivos genéricos se sumó un cuarto objetivo que iba a condicionar la obra. El hecho de conservarse en un estado aceptable la mayor parte de elementos decorativos y litúrgicos de la iglesia, y la voluntad de cooperar en la reivindicación de una época artística infravalorada en Cataluña, nos sugirió la idea de repetir en Muntanyola una actuación similar a la que hicimos años atrás en Sant Vicenç de Rus. De aquella iglesia románica recuperamos científicamente sus elementos constructivos y decorativos para facilitar a sus visitantes la comprensión de la arquitectura del siglo XII (3). En Muntanyola podíamos hacer lo mismo con 
relación al barroco, con la ventaja de que sólo debíamos poner en valor cuanto ya teníamos; es decir, podíamos plantear una restauración ambiental con fines didácticos, una restauración didáctica. Con este objetivo y con aquella irrenunciable ambición programática y metodológica, atemperada lógicamente por los recursos disponibles, se plantearon los trabajos.

\section{OCHO AÑOS DE OBRAS}

El largo proceso de restauración ha durado ocho años, no por su complejidad, evidentemente, sino por razones presupuestarias. Como en tantas otras ocasiones, procuramos sin embargo aprovechar los innegables aspectos positivos de esta lentitud, ya que en actuaciones de restauración de este tipo -no

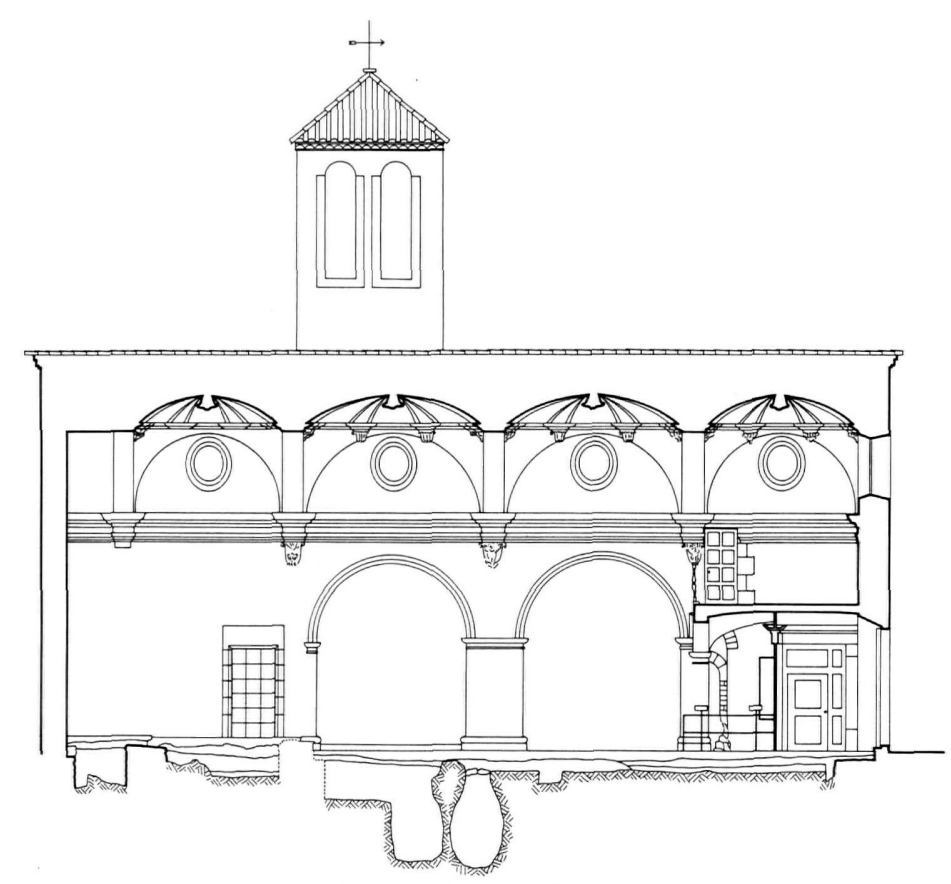

Sección longitudinal con indicación de los estratos arqueológicos.

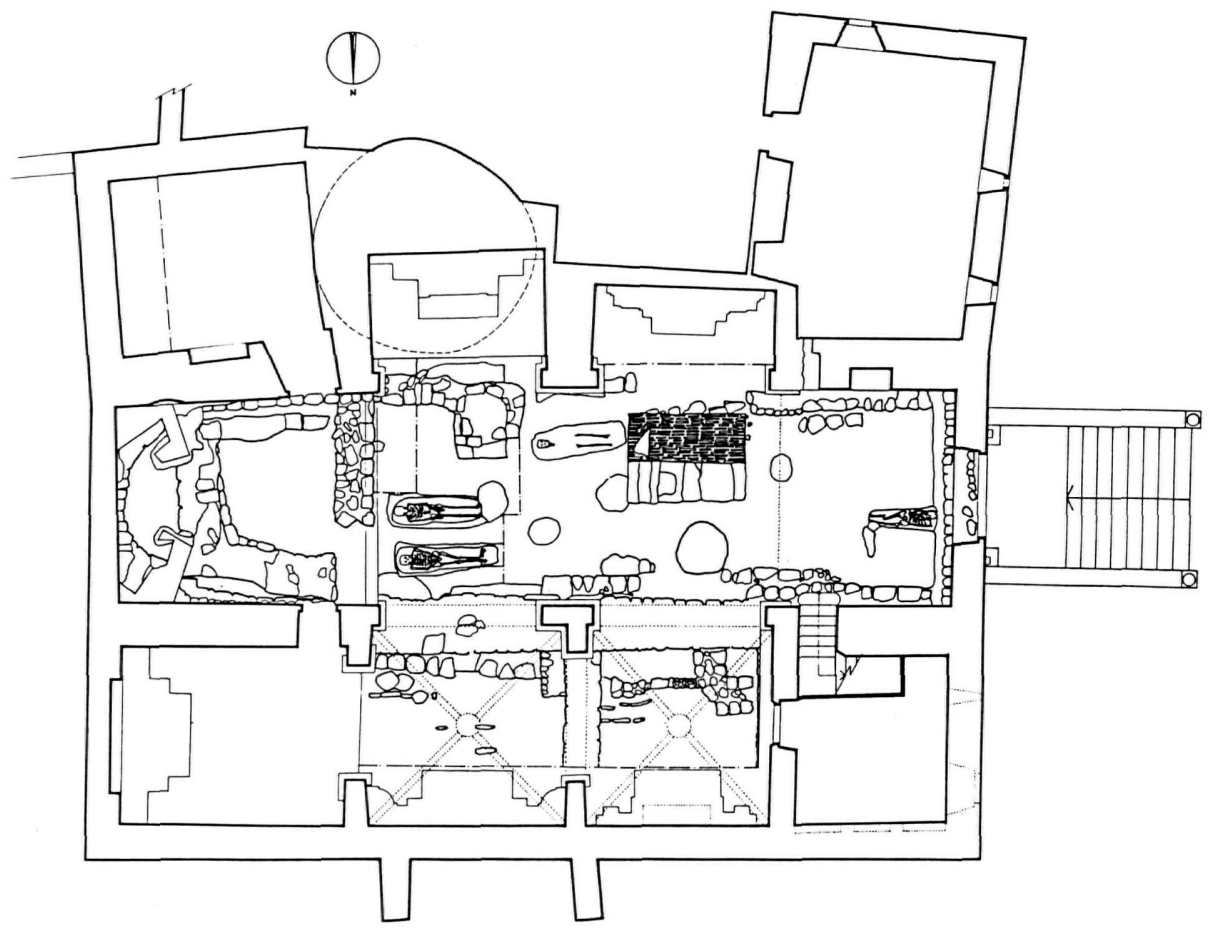

Planta general después de las exicalaciones arqueológicas. 


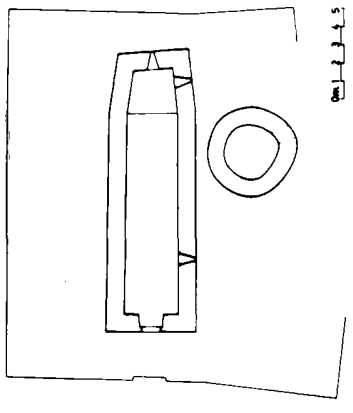

S. X

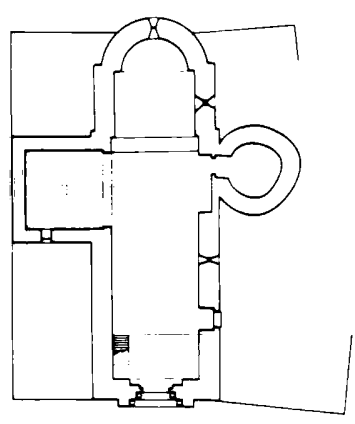

S. XVI

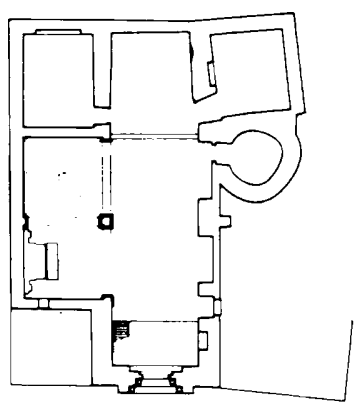

d. 1690

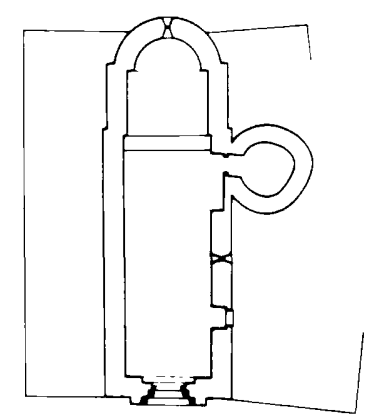

S. Xll

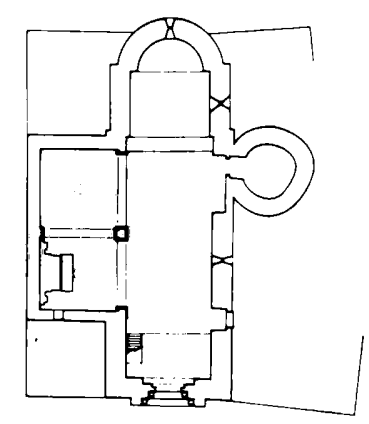

a. 1668

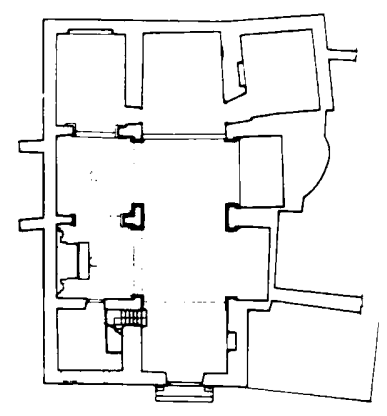

S. XVIII urgidas por emergencias-, favorece la reflexión, la prudencia y el buen tino.

Desde enero de 1984 hasta marzo de 1986 nos dedicamos a programar presupuestos, redactar informes, hacer estudios estructurales y esbozar los primeros proyectos. Durante los dos años siguientes, mientras se iniciaban los estudios históricos, se solventaron algunos de los problemas constructivos más preocupantes. Después, de marzo de 1988 a febrero de 1989, se realizó la excavación arqueológica mientras se restauraba el campanario. Y a partir de 1990 se inició la restauración definitiva del interior y la adecuación del entorno, trabajos que concluyeron el mes de noviembre de 1992, a excepción de la restauración de algunos retablos.
Los estudios previos de carácter físico-constructivo no supusieron más que una detenida inspección ocular de las fábricas, algún sencillo cálculo tipo cuele dos partido por ocho y la observación de unos cuantos testigos de yeso. Compartimos la creencia de que no siempre son indispensables los modelos matemáticos o los oscilómetros de precisión para conocer o prever el comportamiento de un edificio, por lo que rechazamos echar mano por rutina de los complejos recursos analíticos que hoy nos brinda la técnica.

Para los estudios históricos, sin embargo, se recurrió a todos los resortes posibles: la investigación arqueológica, con los trabajos complementarios habituales (ceramología, numismática, antropología física), el análisis de la documentación conservada (que proporcionó una abundantísima información), el análisis desde la historia del arte, y el análisis históricoconstructivo, es decir, desde la historia de la construcción. Así pudimos pasar de los escasos datos que facilitan las enciclopedias sobre Sant Quirze de Muntanyola (" ... iglesia ya citada el año 957, renovada y consagrada en 1177 , y, de nuevo, en el siglo XVIII... ") a una datación pormenorizada de todas las fábricas y elementos del edificio.

\section{CUBIERTAS Y MUROS}

A nuestra llegada a Muntanyola el estado de las cubiertas era lamentable. Las tejas apenas cumplian su cometido de conducir las aguas pluviales, y las estructuras leñosas que las soportaban habían llegado al colapso. Las rudimentarias cerchas de madera, que no tenían ningún interés especial, fueron sustituidas por viguetas de hormigón prefabricadas, elementos de uso habitual hoy en la comarca, y las sencillas bóvedas interiores fueron descargadas de pesos no previstos. Para tejar de nuevo se utilizaron tejas árabes tradicionales, en buena parte recuperadas del propio edificio. Como pedía nuestro maestro Martorell, ampliamos las canaleras de lima hoya como medida preventiva indispensable para garantizar una mayor durabilidad a la nueva cubierta.

En la sustitución de la estructura del tejado del campanario, también en mal estado de conservación, debido a que presentaba más interés y era visible desde el interior, el criterio fue distinto. Mediante una grúa fue bajada la estructura sin desmontar y, una vez abajo, los carpinteros hicieron una réplica con el mismo tipo de madera - protegida ahora de los xilófagos-, aprovechando de la vieja todos los elementos metálicos aún útiles. Un mes y medio después de bajar la estructura original, la nueva -a 
nuestro juicio tan auténtica como aquélla-, se subió por el mismo procedimiento y se colocó sobre un zuncho de hormigón para nivelar y repartir las cargas. Las tejas utilizadas fueron en este caso vidriadas, fabricadas por encargo en la Bisbal d’Empordà, ya que al desmontar el antiguo tejado se encontraron suficientes indicios de que las originales habían sido de este tipo.

La consolidación de los muros no ofreció ninguna dificultad especial. Primero se recalzó con hormigón el cimiento de la esquina asentada y se cosieron después las grietas a la manera tradicional: con grapas de hormigón en el relleno interior, y completando las hiladas de la cara exterior con sillarejos del mismo tamaño.

Tampoco supuso ni graves problemas técnicos ni graves dudas conceptuales la recuperación de la imagen exterior de los muros, y por tanto del edificio. A pesar de la devoción que en Cataluña se profesa aún por la mampostería vista no dudamos en recuperar los revestimientos originales. Los restos de enlucidos fueron repicados después de la toma de datos y se procedió a revocar los muros desnudos con mortero de cal enriquecido con cemento portland blanco en baja proporción y a aplicar dos capas de estuco preparado según técnicas tradicionales (mortero de cal con polvo de mármol y pigmentos naturales), técnicas por fortuna aún no olvidadas en la comarca. Los sillares de las esquinas, siguiendo una tradición posiblemente no muy antigua, se dejaron descubiertos, y se obtuvo un resultado no del todo satisfactorio. Hoy creemos que debimos haber estucado la totalidad de los muros, incluidas las aristas.

La portada también fue restaurada, aunque sin reponer todas las faltas de la piedra. El arquitecto se reservó la decisión sobre qué elementos deberían ser o no repuestos, y el escultor sobre qué material se utilizaba, bien la piedra natural, bien el mortero reintegrador. En cuanto a las desvencijadas escaleras, se conservaron y consolidaron los escalones (la mayor parte, fracciones de losas sepulcrales aprovechadas), y los pretiles se acortaron, y fueron separados de la portada contra la que se atracaban antes sin demasiada consideración.

La puerta de doble hoja de la entrada, que llegó a nosotros en estado terminal, se rehízo a la manera tradicional. Compramos madera de roble con un año de antelación para garantizar su secado y, llegado el día, las viejas tablas fueron sustituidas por las nuevas. La estructura y los herrajes fueron conservados. También se restauraron las pocas vidrieras que tiene

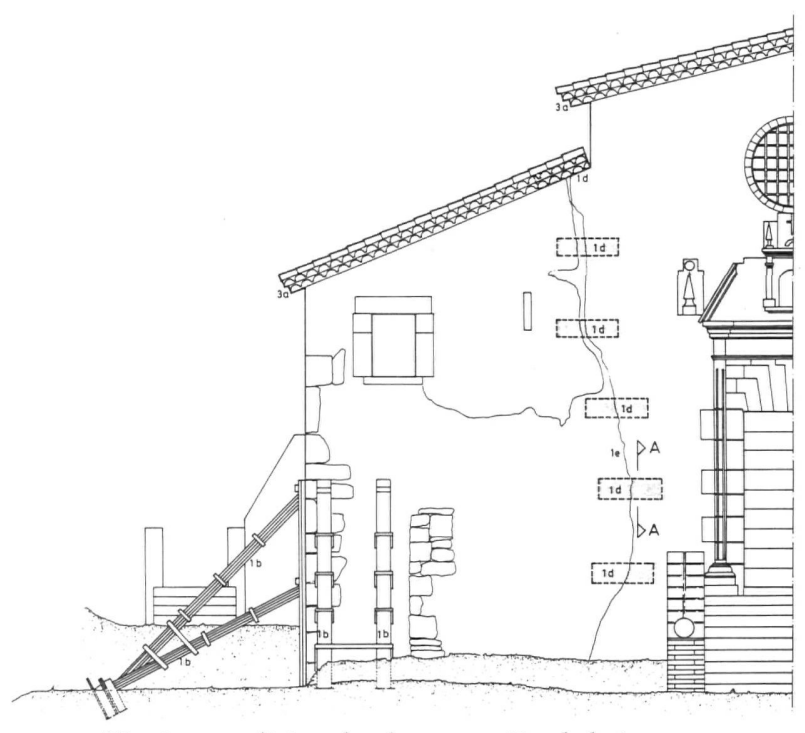

Técnicas tradicionales de reparación de lesiones.

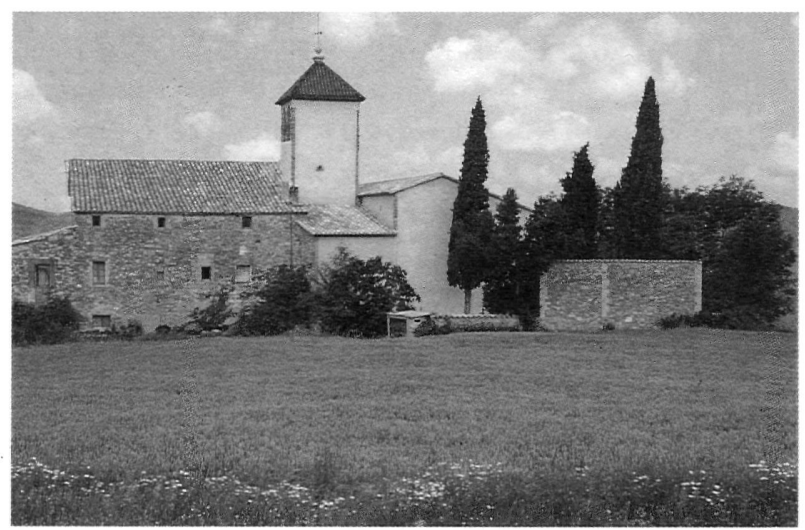

Fachada de levante después de la restauración.

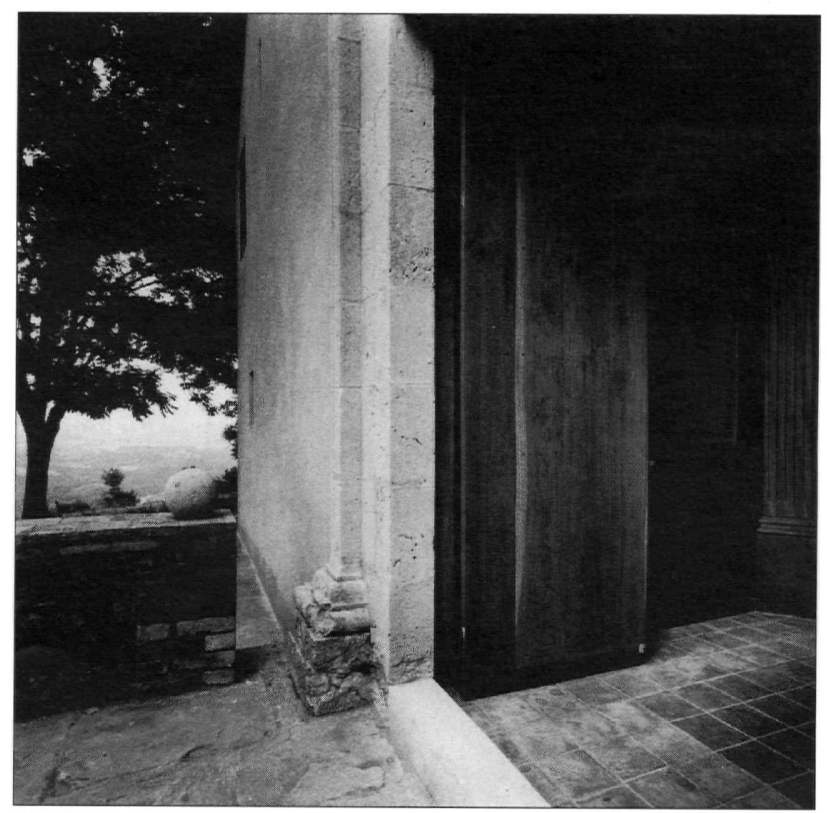

El acceso una vez concluidos los trabajos. 
el edificio, una de ellas -la del pequeño rosetón de la fachada principal- con una simple pero interesante estructura.

\section{RECUPERACIÓN DEL INTERIOR}

En una restauración didáctica como la que se perseguía era fundamental la recuperación ambiental del interior, y no sólo de la nave y las capillas, sino de todos los espacios y elementos que pueden ayudar a definir ese ambiente de iglesia rural concebida y decorada en los dos últimos siglos. Incluso los más obsoletos, como el hoy olvidado rincón del baptisterio de finales del siglo XIX o el púlpito.

El pavimento era también un elemento esencial para definir esa imagen y ese ambiente. Una vez acabadas las excavaciones arqueológicas, que dejaron a la vista la irregular señal que la historia había hollado en el terreno, se niveló toda la superficie interior con grava fina y sobre ella se tendió una lámina de polietileno, para cortar el paso a la humedad, y una plataforma de hormigón de $10 \mathrm{~cm}$ de altura. Sobre ésta, alcanzando la misma cota que los arqueólogos dijeron que tuvo la nave en el siglo XVIII, se dispuso el nuevo pavimento de losas cerámicas manuales fabricadas ex profeso, casi idénticas a las que se colocaron en 1729, de las que en la excavación se habían rescatado algunas muestras. El mosaico hidráulico de

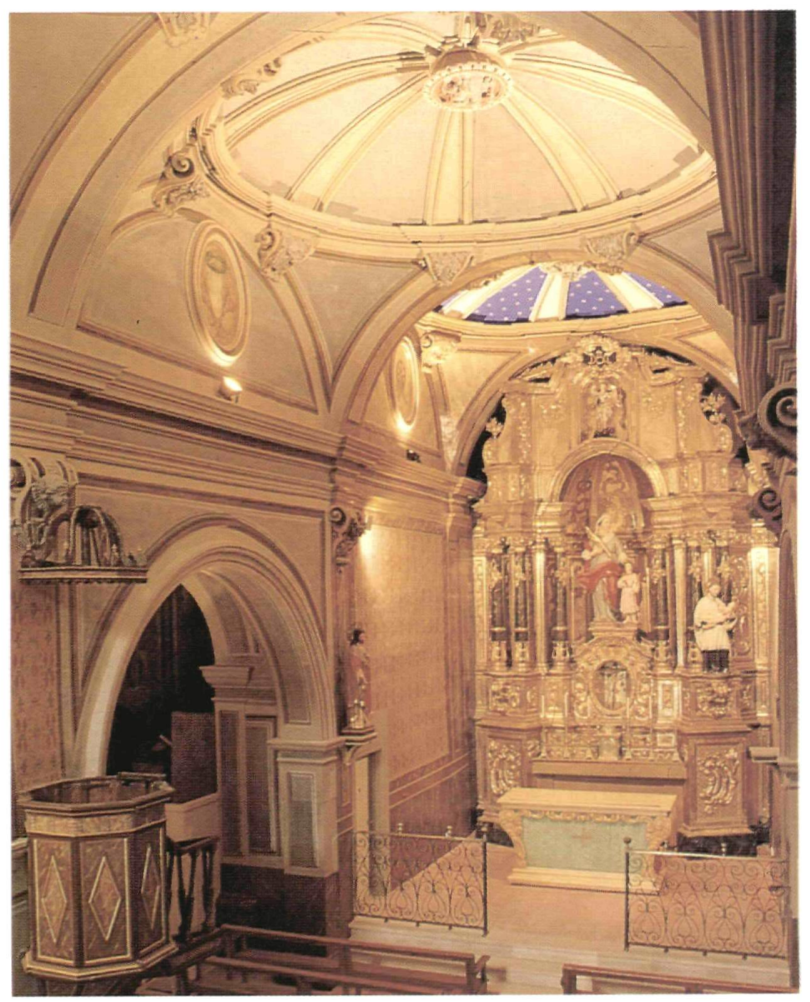

El conjunto después de la restauración.

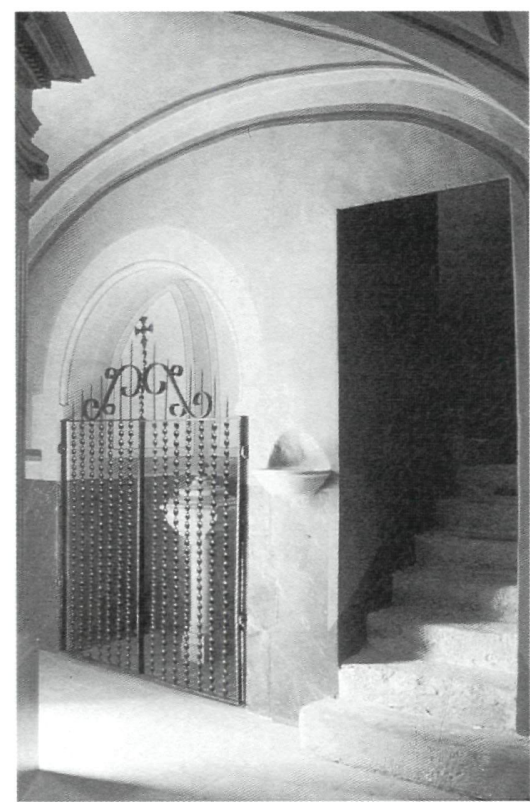

El baptisterio de 1891

nuestro siglo -que lucía en toda la iglesia cuando empezamos nuestra actuación y fue desmontado al iniciarse las excavaciones-, fue conservado como testimonio en algunos espacios marginales del templo, y se guardó el resto en la casa rectoral vecina.

Otro aspecto esencial era, naturalmente, la recuperación de la deteriorada pintura mural. Antes de decidir el criterio a seguir se hicieron sondeos técnicos en diversos puntos de la nave y las capillas. Estas catas estratigráficas fueron realizadas mecánicamente con bisturí o químicamente con disolventes, y se documentaron los resultados en gráficas y muestrarios de color de las diversas capas pictóricas, con los correspondientes exámenes organolépticos sobre su estado de conservación. Se concluyó la existencia en algunas zonas de las capillas y del presbiterio de diversas capas pictóricas anteriores a la ahora vista, todas ellas realizadas con la técnica del temple sobre preparación de yeso, con un grado de conservación muy deficiente en las capas superiores. La mayor parte de la nave sólo presentaba la capa aparente realizada muy probablemente, según la documentación, en 1848 .

Una vez analizado el informe y las propuestas de los especialistas, optamos por conservar -o rehacer allí donde se había perdido- esta última decoración, ya que fue la única que afectó todo el interior del templo, previendo la posibilidad de que más adelante se recupere en una de las capillas la decoración anterior, más interesante y mejor conservada que la del siglo XIX. Se ha utilizado pintura a la cola, no acrílica, tanto para repasar la pintura preexistente como 
para rehacer las superficies perdidas por la humedad, en este caso, previo el rellenado de grietas y el repicado y sustitución, con el mismo material, del yeso en mal estado. En la bóveda del presbiterio no se varió el rutilante azul que encontramos. También limpiamos y recuperamos, sin modificar su ambiente, otros espacios aunque su uso hoy sea mínimo, como la sacristía, con su práctica cómoda para guardar el ajuar y su lavabo, que recuperó la frase latina que lo decora.

De los trabajos de restauración mobiliar, los más importantes eran sin duda la recuperación física y formal de los retablos. El presupuesto sólo nos permitió acometer la restauración parcial del retablo del altar mayor, que fue realizada por los alumnos del departamento de restauración pictórica de la Escuela de Artes y Oficios de la Diputación barcelonesa, dirigidos por las profesoras Anna Miquel y Rosa Gasol. Se ha previsto que los alumnos de la misma escuela completen el trabajo pendiente a partir de 1993, en sucesivas campañas de prácticas.

A los pies del retablo mayor se ha colocado un altar idéntico al original, que fue retirado por su mal estado de conservación. El nuevo, sin embargo, para que el rector pueda decir la misa de cara al pueblo, es móvil, como el que hicimos para la iglesia de Sant Cugat de Gavadons hace unos años (4), y puede avanzarse o reintegrarse a su posición original en el retablo una vez acabada la celebración desplazándose sobre unas guías.

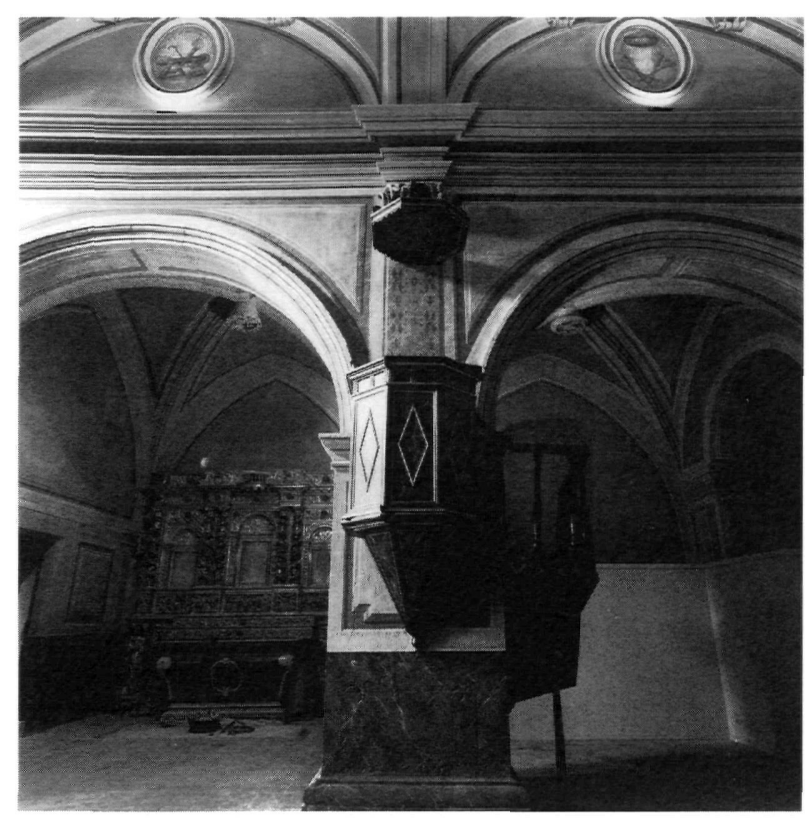

Interior de la nave y las capillas del norte después de la ohra.
En la nave se han conservado los viejos bancos que conservan grabados los gentilicios de las masías del lugar. En esta ocasión, no sólo por motivos económicos, sino sobre todo por motivos conceptuales, no quisimos introducir, como hicimos en otras iglesias -Sant Vicenç de Malla, por ejemplo (5)-, elementos diacrónicos. En Muntanyola hubieran perjudicado la recuperación ambiental perseguida.

\section{LEER LA HISTORIA EN LOS MUROS}

Potenciar la significación colectiva del monumento era otro de nuestros objetivos, ya que la estima de los usuarios hacia el edificio es la mejor garantía de que velen por su conservación. Pero en toda relación de aprecio, amistad o amor, es imprescindible el previo conocimiento. Por ello procuramos siempre reservar una parte del presupuesto disponible para fomentar entre la población ese conocimiento del monumento. Uno de los caminos es facilitar la lectura en la propia fábrica de su evolución histórica. Algo así habíamos hecho en Santa Eulàlia de Riuprimer en 1986 (6).

En el caso de Muntanyola, facilitar la comprensión de la compleja evolución histórica de su iglesia era imprescindible, además, para superar posibles frustraciones. A los catalanes se les ha dicho que la importancia de sus monumentos es proporcional a su relación con la época románica (el cartel de la carretera era elocuente). A los vecinos de

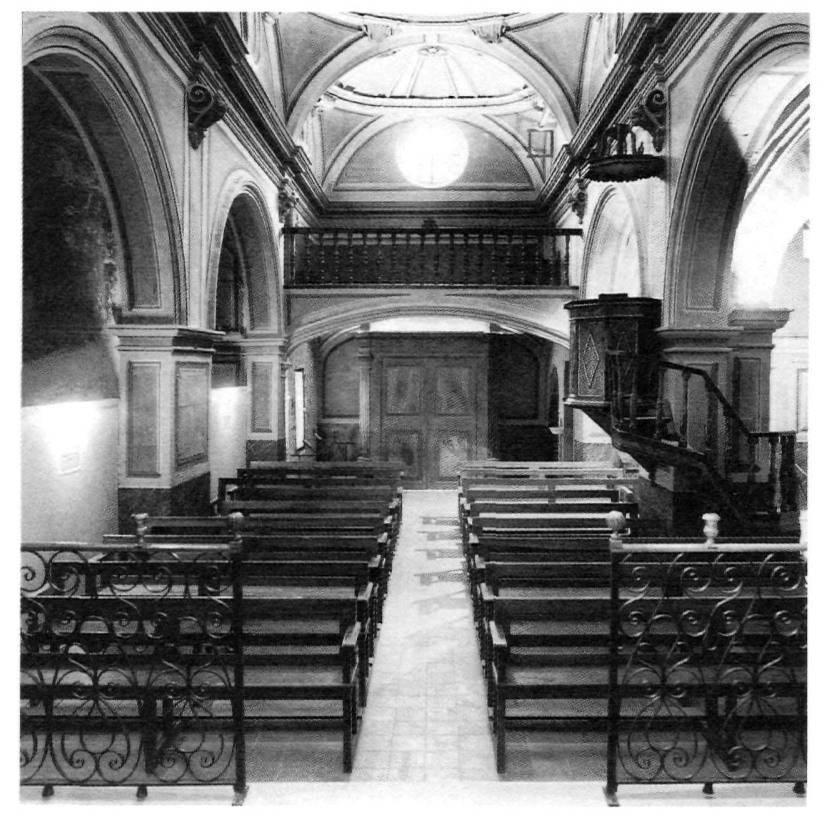

Interior de la nave, después de la restauración. 
40

Informes de la Construcción, Vol. 45 n² 427, septiembre/octubre 1993

Muntanyola no se les podía ocultar el origen medieval de su templo.

Por fortuna, los restos románicos que se conservan - descubiertos en los trabajos de exploración de los muros- tenían una cierta entidad. Por ello, aunque

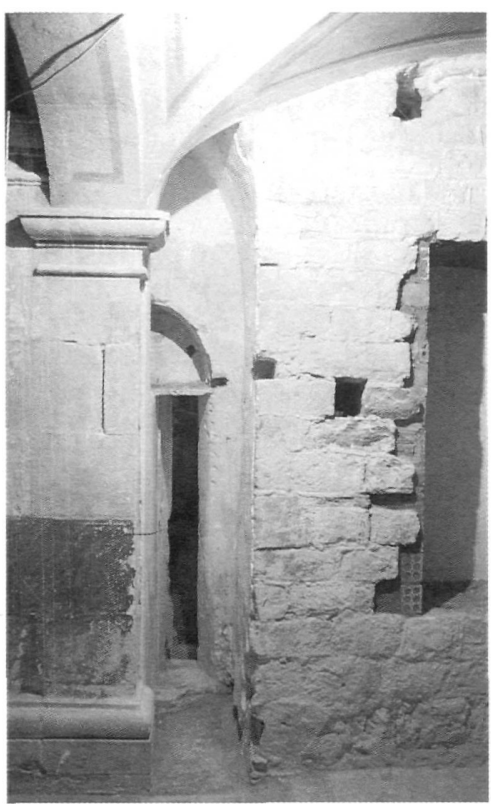

Restos de la iglesia románica hallados al explorar los muros el criterio de la restauración era potenciar la imagen barroca, se decidió dejar vistos algunos de esos paramentos medievales, teniendo en cuenta, además, que por su posición en la nave no alteraban la unidad ambiental recuperada. El más expresivo de estos paramentos es el de la cara interior del muro de mediodía, a los pies del templo, que conserva la junta resaltada característica del siglo XII y un fragmento de la puerta lateral románica. Junto a él, en el hueco de un antiguo armario, se han expuesto un capitel de la portada del siglo XII y otras piedras decorativas de época posterior halladas en la exploración de los muros. Unos atriles que emergen de una baranda informan al espectador sobre las características del muro y de esas piezas expuestas.

Otro lienzo románico, correspondiente a la cara exterior del muro de tramontana del siglo XII, puede verse desde un espacio marginal para el uso cultual de la iglesia, pero que después de la restauración ha cobrado un gran interés. En ese espacio se han colocado-como hemos hecho en otras iglesias- planos y una vitrina con cinco maquetas, que representan el estado del templo en cinco momentos sucesivos de su evolución, con la finalidad de facilitar al visitante la comprensión de ese devenir. También dejamos a la vista, aunque sin exhibicionismos, algunas super-

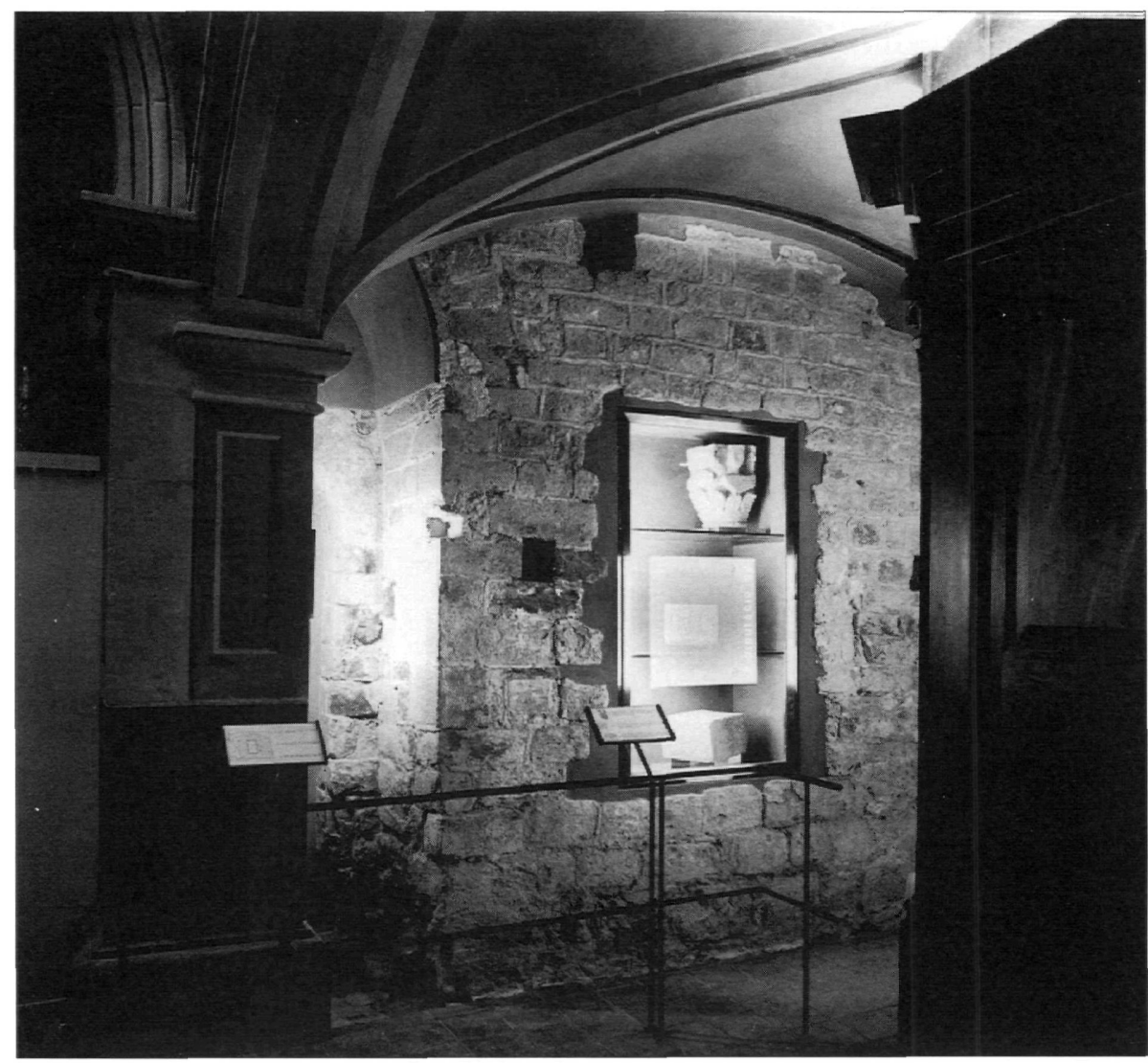

Restos románicos dejados a la vista. 
posiciones. Una sección de la base de la pilastra de la capilla septentrional reformada en el siglo XVIII permite ver la base anterior correspondiente a la capilla primitiva del siglo XVII. La uniformidad de la pintura que cubre ambas bases hace que sólo un espectador curioso o entendido aprecie el detalle.

\section{TRATAMIENTO DEL ENTORNO}

Otro aspecto de la actuación fue la mejora del entorno. No me refiero al tradicional concepto de entorno monumental (que tiene como objeto mejorar la visibilidad del monumento o dar normativas estéticas para construir cerca), sino al entorno de uso: es decir, el que se define pensando en el usuario más que en el monumento; pero no tanto por motivos prácticos (mejorar la accesibilidad, por ejemplo), sino por motivos significativos. En las actuaciones en Sant Miquel de Terradelles (1982) (7) y Santa Càndia d'Orpí (1985) (8), la intervención en el entorno nos ayudó a potenciar la relación significativa entre usuario y edificio, cuyo espacio interior, con todos sus significados emblemáticos, parece desparramarse por ese entorno.

La actuación alrededor de la iglesia de Muntanyola estuvo presidida por esa misma voluntad, pero estuvo condicionada también por la conveniencia de recuperar la cota perdida al abrir el camino contiguo al ángulo noroeste, lo que, como vimos, había afectado el cimiento y las escaleras que fueron modificadas al realizar el rebaje del terreno. Al alejar nosotros el camino se pudo recuperar un pequeño espacio en

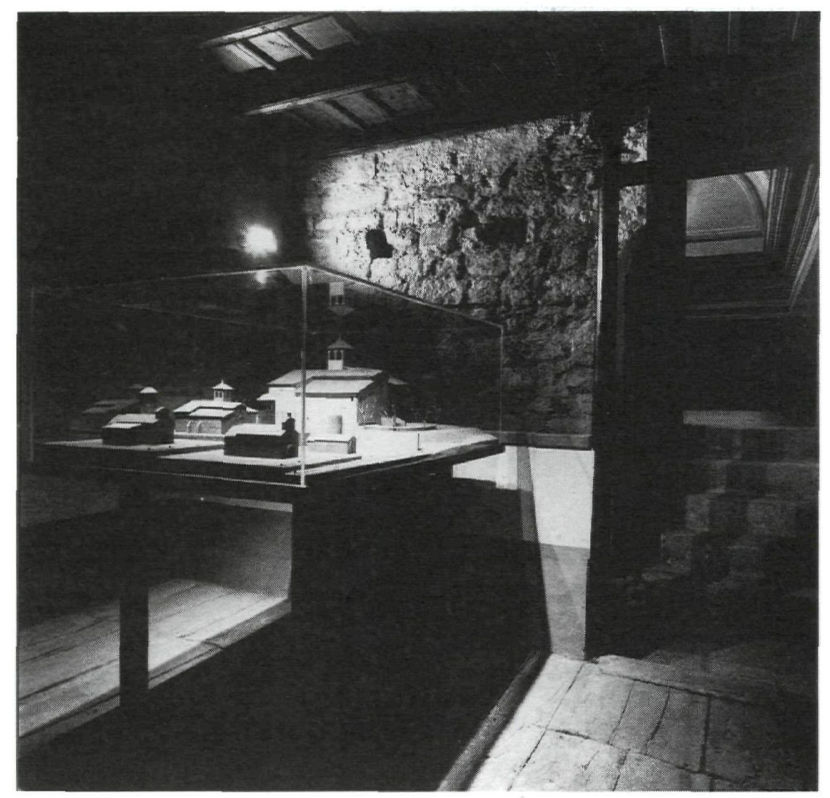

Conjunto de maquetas explicativas de la evolución del templo.

la cota original, delimitado por la prolongación del muro del cementerio que gira por delante de la iglesia como abrazándola. El tramo final del muro hace de banco y se encara a los poyetes adosados a la iglesia que sirven también de banco y sirve, además, para disimular el nuevo cimiento.

Antes se accedía al cementerio a través de una puerta -que llegó a nosotros decrépita-, precedida por tres escalones, que en los entierros dificultaban el tránsito de la comitiva. La prolongación del muro nos permitió crear una suave rampa de acceso al camposanto. En cuanto al recinto funerario hemos

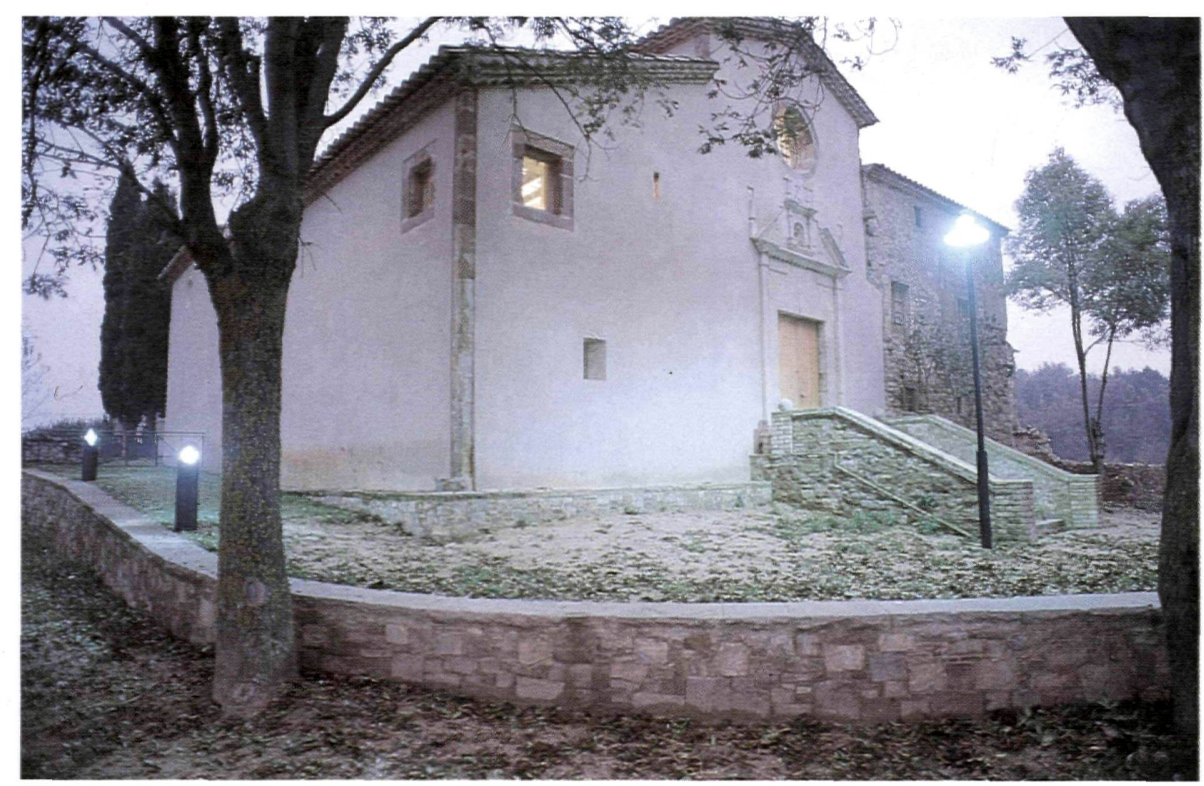

El conjunto después de la restauración 
atendido el mandato de que este tipo de espacios sagrados debe mantenerse cercado. La nueva valla de hierro, pintada con una mezcla de pintura gris oscuro del tipo "oxirón" y pintura plástica convencional verde inglés, cumple también el papel de barandilla. Se trata de una sencilla retícula en la que las riostras y los montantes se mueven con independencia en dos planos paralelos. En cuanto a la fecha grabada en la doble hoja de la portezuela, 1991, se trata de una pequeña licencia, ya que la puerta se colocó en 1990, pero no se pudo resistir el atractivo de la simetría de aquel guarismo.
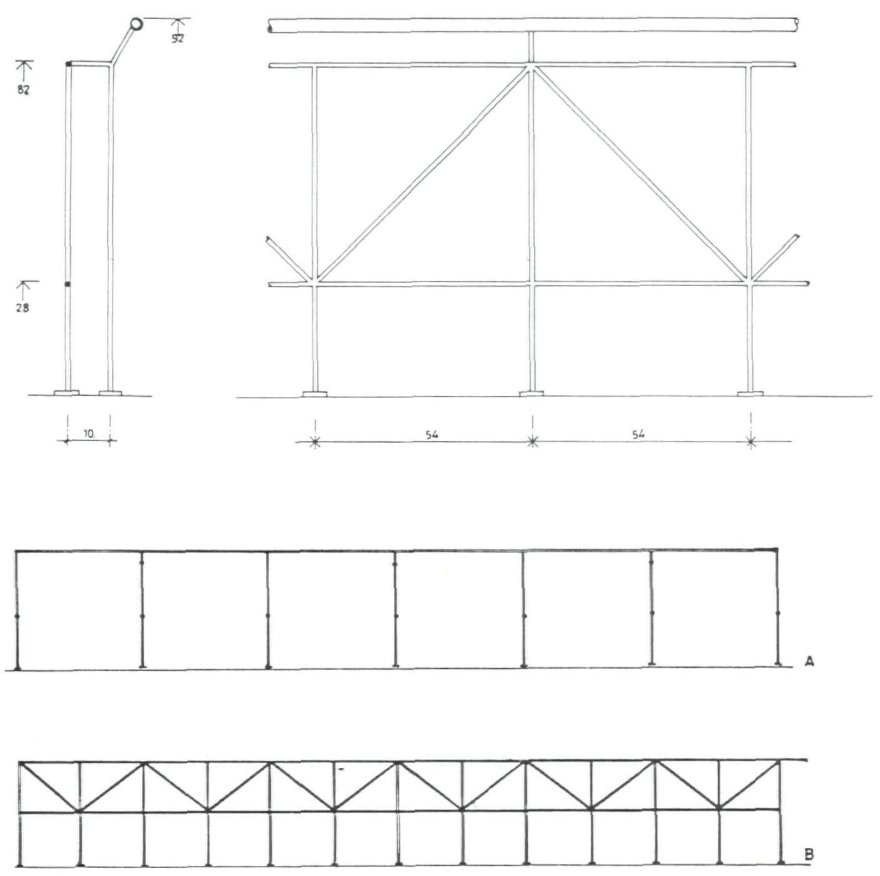

Junto a las escaleras, como hicimos en Sant Miquel de Terradelles, colocamos un farol de encendido automático que permitirá ampliar el horario de uso de la iglesia y permitirá perpetuar en el paisaje del municipio, en su punto más alto, la presencia de su hito arquitectónico más significativo. Las obras en el entorno se aprovecharon para soterrar el tendido eléctrico y liberar al edificio de palomillas.

Tanto al final de la carretera como junto a la entrada de la iglesia el visitante es ahora advertido de la complejidad histórica del edificio por medio de car-

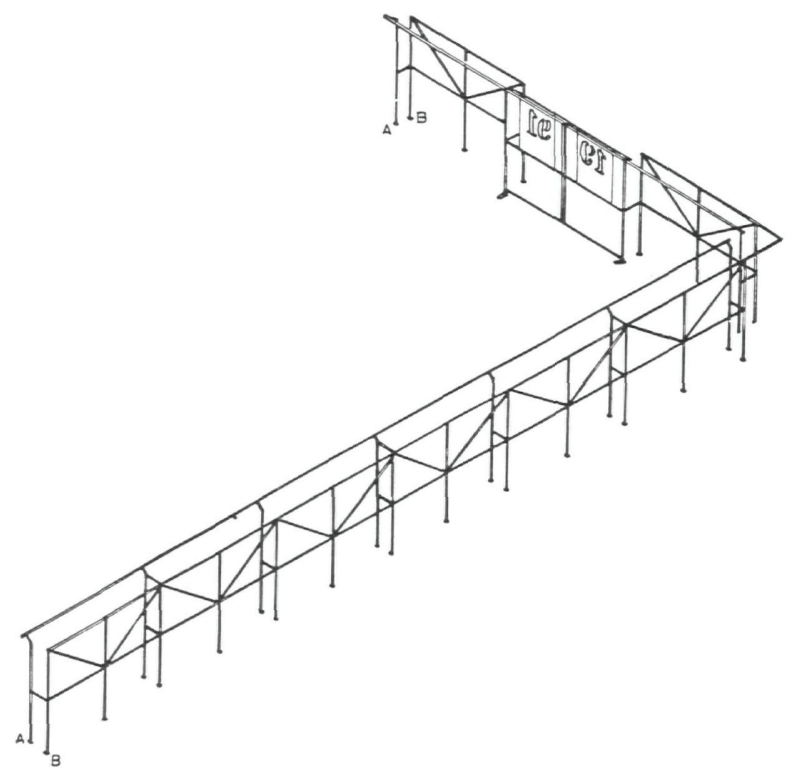

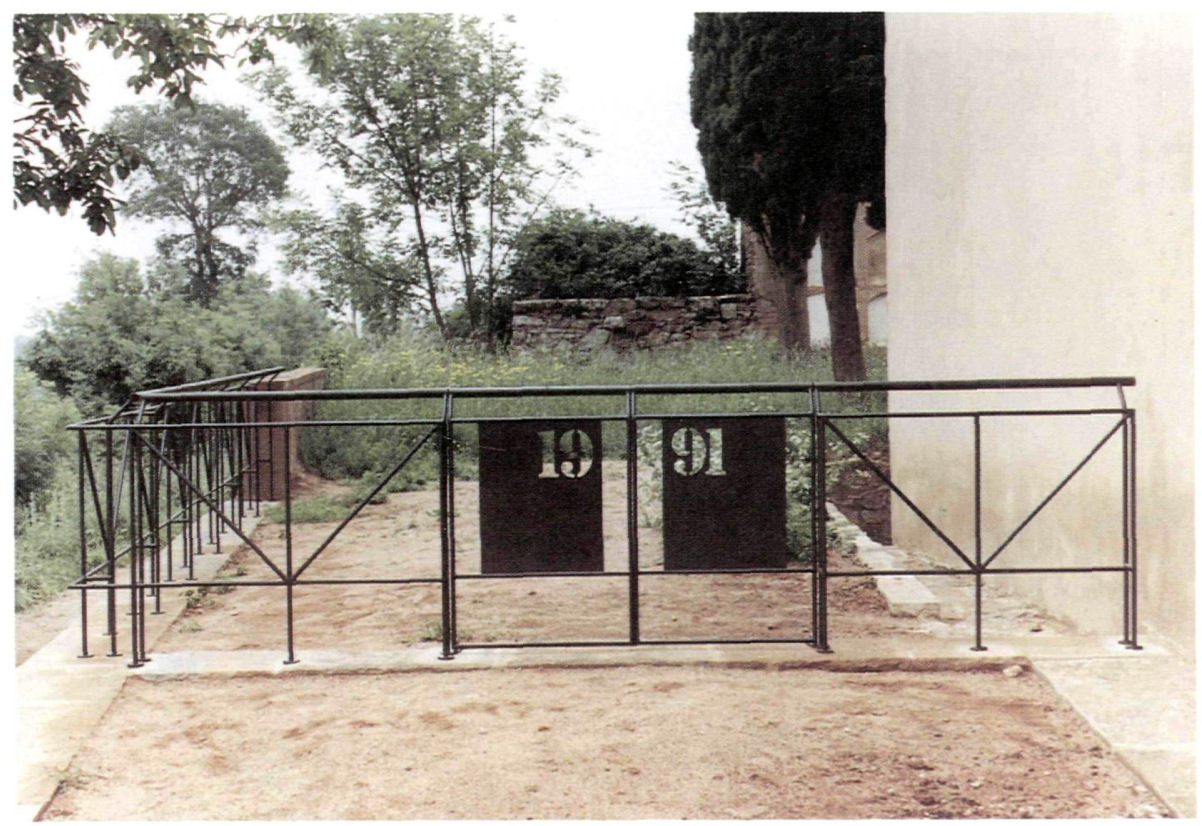

El nuevo cerramiento del cementerio. 
teles que rezan así: Església de Sant Quirze $i$ Santa Julita de Muntanyola. Segles X al XVIII, y que sustituyen el de nuestros compañeros de carreteras que tanto nos sorprendió.

Como es habitual en nuestras obras, la información se completa con una pequeña publicación, cuyos ejemplares se reparten entre los vecinos el día de la celebración del fin de las obras o se dejan en el lugar para satisfacer la curiosidad de los visitantes. Un gesto que no consideramos ajeno o posterior a la restauración, sino que forma parte, como último eslabón de su metodología, especialmente cuando se trata, como en este caso, de una restauración didáctica.
(1) Antoni González Moreno-Navarro, "Restaurar monumentos, una metodología específica", en Informes de la Construcción, n 397, Madrid, septiembre/octubre de 1988.

(2) Jeroni Martorell Terrats, "El patrimonio artístico nacional. (Conferencia en el Ateneo de Madrid, por Jerónimo Martorell)", en Arquitectura, n 14. Madrid, junio de 1919

(3) Informes de la Construcción, n 397, p. 45.

(4) Lluís de Grassot, "Iglesia de Sant Cugat de Gavadons", en On Diseño, $\mathrm{n}^{2} 102$, Barcelona, 1989.
(5) Informes de la Construcción, nº 397, p. 32.

(6) Informes de la Construcción, n² 397, p. 41.

(7) "Església vella de Sant Miquel de Terradelles", en Antoni González y otros, La restauració, ara i aquí, Memòria 1981-1982. Servicio de Patrimonio Arquitectónico de la Diputación de Barcelona, Barcelona, noviembre de 1983.

(8) Antoni González y otros, Església de Santa Càndia d’orpi, Monografías del Servicio del Patrimonio Arquitectónico de la Diputación de Barcelona, n 1, Barcelona, julio de 1989.

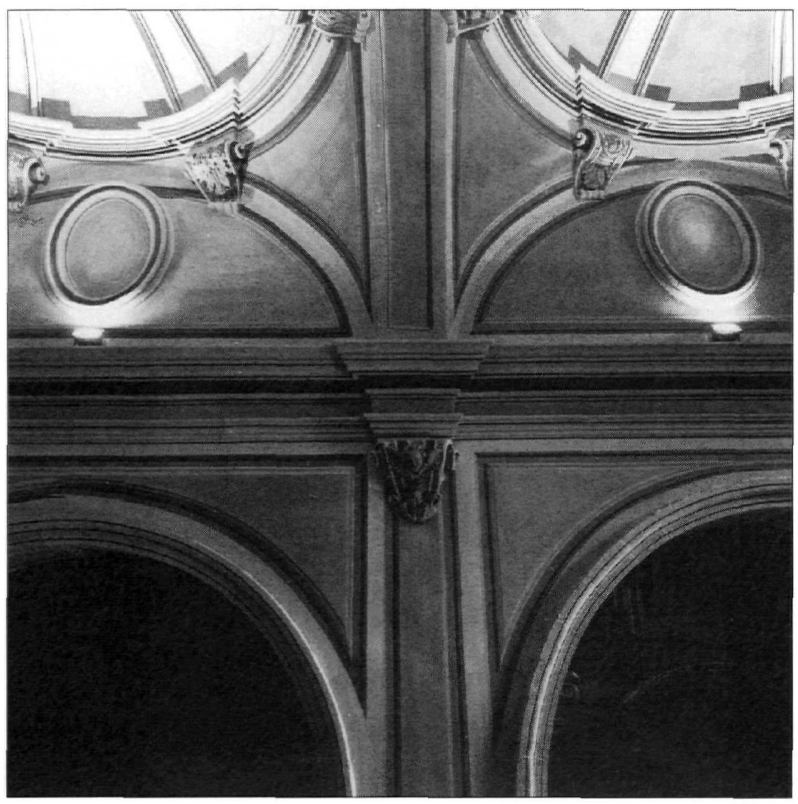

Ficha Técnica

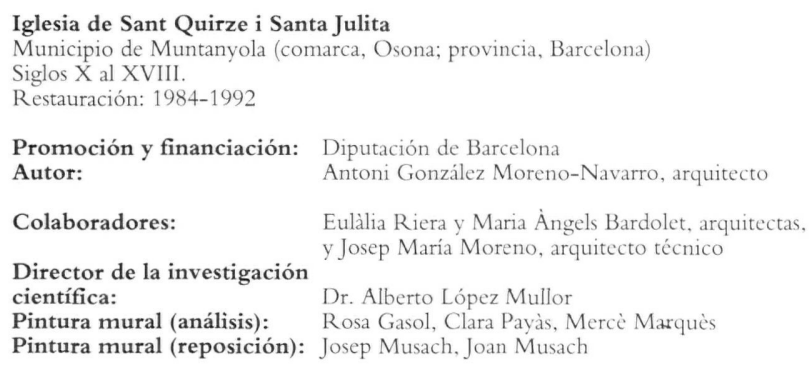

Promoción y financiación: Diputación de Barcelona

Autor: Antoni González Moreno-Navarro, arquitecto

Colaboradores: $\quad$ Eulàlia Riera y Maria Ȧngels Bardolet, arquitectas,

Director de la investigación

científica: Dr. Alberto López Mullor

Pintura mural (análisis): Rosa Gasol, Clara Payàs, Mercè Marquè

Pintura mural (reposición): Josep Musach, Joan Musach 